\title{
Genetic interventions and the ethics of enhancement of human beings
}

\author{
Julian Savulescu \\ Uehiro Chair in Practical Ethics. Director of the Oxford Uehiro Centre for Practical Ethics. University of Oxford \\ julian.savulescu@philosophy.ox.ac.uk
}

TECNOLOGÍAS DE MEJORA HUMANA: DEBATE ÉTICO E IMPACTO SOCIOCULTURAL
MONOGRÁFICO COORDINADO POR MIGUEL MORENO (Universidad de Granada) y FRANCISCO LARA (Universidad de Granada)

\section{RESUMEN}

Los aspectos éticos del mejoramiento humano han sido objeto de un intenso debate. Numerosos autores bien conocidos se han involucrado en él o se han mostrado críticos con el uso de tecnologías capaces de modificar o mejorar a los seres humanos. Quiero argumentar que tenemos una obligación moral o una razón moral para mejorarnos a nosotros mismos y a nuestros hijos, no solo que se trata de algo meramente permisible. En realidad, tenemos el mismo tipo de obligación que tenemos de tratar y prevenir enfermedades. No solo podemos mejorar: deberíamos mejorar.

\section{ABSTRACT}

There has been considerable recent debate on the ethics of human enhancement. A number of prominent authors have been concerned about or critical of the use of technology to alter or enhance human beings. I want to argue that far from being merely permissible, we have a moral obligation or moral reason to enhance ourselves and our children. Indeed, we have the same kind of obligation as we have to treat and prevent disease. Not only can we enhance, we should enhance.

\footnotetext{
PALABRAS CLAVE
}

mejora biológica en humanos | mejora ética | autonomía procreativa | mejora cognitiva | tecnologías externas de mejora KEYWORDS

biological enhancement in humans | ethical enhancement | procreative autonomy | cognitive enhancement | external enhancing technologies

\section{Genetic interventions and the ethics of enhancement of human beings * \\ Should we use science and medical technology not just to prevent or treat disease, but to intervene at the most basic biological levels to improve biology and enhance people's lives? By enhance, I mean help them to live a longer and/or better life than normal. There are various ways in which we can enhance people but I want to focus on biological enhancement, especially genetic enhancement.}

There has been considerable recent debate on the ethics of human enhancement. A number of prominent authors have been concerned about or critical of the use of technology to alter or enhance human beings (Annas 2000: 753-782, Elliott 2003) citing threats to human nature and dignity as one basis for these concerns (Fukuyama 2003, Kass 2002, Habermas 2003). The President's Council Report entitled Beyond Therapy was strongly critical of human enhancement. (President's Council on Bioethics 2003) Michael Sandel, in a widely discussed article, has suggested that the problem with genetic enhancement 'is in the hubris of the designing parents, in their drive to master the mystery of birth (...) it would disfigure the relation between parent and child, and deprive the parent of the humility and enlarged human sympathies that an openness to the unbidden can cultivate (...). [T] he promise of mastery is flawed. It threatens to banish our appreciation of life as a gift, and to leave us with nothing to affirm or behold outside our own will" (Sandel 2004).

Frances Kamm (2005) has given a detailed rebuttal of Sandel's arguments, arguing that human enhancement is permissible. Nicholas Agar, in his book, Liberal Eugenics, argues that enhancement should be permissible but not obligatory. He argues that what distinguishes liberal eugenics from the objectionable eugenic practices of the Nazis is that it is not based on a single conception of a desirable genome and that it is voluntary and not obligatory.

In this chapter, I will take a more provocative position. I want to argue that far from being merely permissible, we have a moral obligation or moral reason to enhance ourselves and our children. Indeed, 
we have the same kind of obligation as we have to treat and prevent disease. Not only can we enhance, we should enhance.

I will begin by considering the current interests in and possibilities of enhancement. I will then offer 3 arguments that we have very strong reasons to seek to enhance.

Tom Murray concludes his thoughtful and wide ranging treatment of enhancement in this volume by arguing that 'the ethics of enhancement must take into account the meaning and purpose of the activities being enhanced, their social context, and the other persons and institutions affected by them'. Such caution is no doubt well grounded. But it should not blind us to the very large array of cases where biological modification will improve the opportunities of an individual to lead a better life. In such cases, we have strong reasons to modify ourselves and our children. Indeed, to fail to do so would be wrong. Discussion of enhancement can be muddied by groundless fears and excessive caution and qualification. I will outline some ethical constraints on the pursuit of enhancement.

\section{Current Interest in Enhancement}

There is great public interest in enhancement of people. Women employ cosmetic surgery to make their nose smaller, their breasts larger, their teeth straighter and whiter, to make their cheekbones higher, their lips bigger and to remove wrinkles and fat. Men, too, employ many of these measures, as well as pumping their bodies with steroids to increase muscle bulk. The beauty industry is testimony to the attraction of enhancement. Body art, such as painting and tattooing, and body modification, such as piercing, have, since time began, represented ways in which humans have attempted to express their creativity, values and symbolic attachments through changing their bodies.

Modern professional sport is often said to be corrupted by widespread use of performance enhancing drugs, such as human erythropoietin, anabolic steroids, and growth hormone. However, some effective performance enhancements are permitted in sport, such as the use of caffeine, glutamine and creatine in diets, salbutamol, hypoxic air tents, and altitude training.

Many people attempt to improve their cognitive powers through the use of nicotine, caffeine, and drugs like Ritalin and Modavigil.

Mood enhancement typifies modern society. People use psychological "self-help", prozac, recreational drugs, and alcohol to feel more relaxed, socialize better, and feel happier.

Even in the most private area of sexual relations, many want to be better. Around $34 \%$ of all men aged 40-70 -around 20 million in the US- have some erectile dysfunction which is a part of normal aging. There is a $12 \%$ decline in erectile function every decade normally. As a result, 20 million men world wide use Viagra (Cheitlin 1999).

More radical forms of biological enhancement appear possible. Even if all disease (heart disease, cancer, etc.) were cured, the average human life span would only be extended by 12 years (Sarah Harper, personal communication). However, stem cell science has the potential to extend human lifespan radically further than this, by replacing aging tissue with healthy tissue (Harris 2000, 2004, 2002). We could live longer than the current maximum of 120 years.

But instead of the radical prolongation of length of life, I want to focus on the radical improvement in quality of life through biological manipulation. Some sceptics believe this is not possible. The skeptic claims that it is our environment, or culture, that defines us, not genetics. But a quiet walk in the park demonstrates the power of a great genetic experiment: dog breeding. It is obvious that different breeds of dog differ in temperament, intelligence, physical ability, and appearance. No matter what the turf, a Doberman will tear a Corgi to pieces. You can debilitate a Doberman through neglect and abuse. And you can make him prettier with a bow. But you will never turn a Chihuahua into a Doberman through grooming, training, and affection. Dog breeds are all genetic -for over ten thousand years we have bred some 300-400 breeds of dog from early canids and wolves. The St. Bernard is known for its size, the Greyhound for its speed, the Bloodhound for its sense of smell. There are freaks, hard workers, vicious aggressors, docile pets, and ornamental varieties. These characteristics have been developed by a crude 
form of genetic selection -selective mating or breeding.

Today we have powerful scientific tools in animal husbandry -genetic testing, artificial reproduction and cloning are all routinely used in the farming industry to create the best stock. Scientists are now starting to look at a wider range of complex behaviours. Changing the brain's reward centre genetically may be the key to changing behaviour.

Gene therapy has been used to turn lazy monkeys into workaholics by altering the reward centre in the brain (Liu 2004). In another experiment, researchers used gene therapy to introduce a gene from the monogamous male prairie vole, a rodent which forms life-long bonds with one mate, into the brain of the closely related but polygamous meadow vole (Lim 2004). Genetically modified meadow voles became monogamous, behaving like prairie voles. This gene, which controls a part of the brain's reward centre different to that altered in the monkeys, is known as the vasopressin receptor gene. It may also be involved in human drug addiction.

Radical enhancements may come on the back of very respected research to prevent and treat disease. Scientists have created a rat model of the genetic disease, Huntington Disease. This disease results in progressive rapid dementia at about 40 . Scientists found that rats engineered to develop Huntington disease who were placed in a highly stimulating environment (of mazes and coloured rings and balls) did not go on to develop this disease -their neurons remained intact (van Dellen 2000, Spires 2004).

Remotivation therapy improves functioning in humans, suggesting environmental stimulation in this genetic disease may affect brain biology at the molecular level (by altering neurotrophins) (Sullivan 2001). Prozac has also been shown to produce a beneficial effect in humans suffering from Huntington Disease (De Marchi 2001). Neural stem cells have also been identified which could potentially be induced to proliferate and differentiated (Rietze 2001), mediated through nerve growth factors and other factors (Palma 2005). We now know that a stimulating environment, drugs like Prozac, and nerve growth factors can affect nerve proliferation and connections -that is our brain's biology. These same interventions -stimulating environment, Prozac, nerve growth factors- could, at least in theory, be used to increase the neuronal complement of normal brains and increase cognitive performance in normal individuals.

IQ has been steadily increasing since first measured, about 20 points per decade. This has been called the Flynn effect (Holloway 1999). Large environmental effects have been postulated to account for this effect (Dickens 2001). The capacity to increase IQ is significant. Direct biological enhancement could have an equally if not greater effect on increase in IQ.

But could biological enhancement of human beings really be possible? Selective mating has been occurring in humans ever since time began. Facial asymmetry can reflect genetic disorder. Smell can tell us whether our mate will produce the child with the best resistance to disease. We compete for partners in elaborate mating games and rituals of display which sort the best matches from the worst. As products of evolution, we select our mates, both rationally and instinctively, on the basis of their genetic fitness -their ability to survive and reproduce. Our (subconscious) goal is the success of our offspring.

With the tools of genetics, we can select offspring in a more reliable way. The power of genetics is growing. Embryos can now be tested not only for the presence of genetic disorder (including some forms of bowel and breast cancer), but also for less serious genetic abnormalities, such as dental abnormalities. Sex can be tested for too. Adult athletes have been genetically tested for the presence of the ACTN3 gene to identify potential for either sprint or endurance events. Research is going on in the field of behavioural genetics to understand the genetic basis of aggression and criminal behaviour, alcoholism, anxiety, antisocial personality disorder, maternal behaviour, homosexuality, and neuroticism.

While at present there are no genetic tests for these complex behaviours, if the results of recent animal studies into hard work and monogamy apply to humans, it may be possible in the future to genetically change how we are predisposed to behave. This raises a new question: should we try to engineer better, happier people? While at present genetic technology is most efficient at selecting among different embryos, in the future it will be possible to genetically alter existing embryos, with considerable progress already being made to the use of this technology for permanent gene therapy of disease (Urnov 2005). There is no reason that such technology could not be used to alter non-disease genes in the future. 
The Ethics of Enhancement

"We want to be happy people, not just healthy people"

I will now give 3 arguments in favour of enhancement and then consider several objections.

\section{First Argument for Enhancement: Choosing Not to Enhance Is Wrong.}

Consider the case of the Neglectful Parents. The Neglectful parents give birth to a child with a special condition. The child has a stunning intellect but requires a simple, readily available, cheap dietary supplement to sustain his intellect. But they neglect the diet of this child and this results in a child with a stunning intellect becoming normal. This is clearly wrong.

But now consider the case of the Lazy Parents. They have a child who has a normal intellect but if they introduced the same dietary supplement, the child's intellect would rise to the same level as the child of the Neglectful Parent. They can't be bothered with improving the child's diet so the child remains with a normal intellect. Failure to institute dietary supplementation means a normal child fails to achieve a stunning intellect. The inaction of the Lazy Parents is as wrong as the inaction of the Neglectful parents. It has exactly the same consequence: a child exists who could have had a stunning intellect but is instead normal.

Some argue that it is not wrong to fail to bring about the best state of affairs. This may or may not be the case. But in these kinds of case, when there are no other relevant moral considerations, the failure to introduce a diet which sustains a more desirable state is as wrong as the failure to introduce a diet which brings about a more desirable state. The costs of inaction are the same, as are the parental obligations.

If we substitute "biological intervention" for "diet", we see that in order not to wrong our children, we should enhance them. Unless there is something special and optimal about our children's physical, psychological, or cognitive abilities, or something different about other biological interventions, it would be wrong not to enhance them.

\section{Second Argument: Consistency.}

Some will object that, while we do have an obligation to institute better diets, biological interventions like genetic interventions are different to dietary supplementation. I will argue that there is no difference between these interventions.

In general, we accept environmental interventions to improve our children. Education, diet, and training are all used to make our children better people and increase their opportunities in life. We train children to be well behaved, co-operative, and intelligent. Indeed, researchers are looking at ways to make the environment more stimulating for young children to maximize their intellectual development. But in the study of the rat model of Huntington's Disease, the stimulating environment acted to change the brain structure of the rats. The drug Prozac acted in just the same way. These environmental manipulations do not act mysteriously. They alter our biology.

The most striking example of this is a study of rats which were extensively mothered and rats who were not mothered. The mothered rats showed genetic changes (changes in the methylation of the DNA) which were passed on to the next generation. As Michael Meaney has observed, "Early experience can actually modify protein-DNA interactions that regulate gene expression" (Society for Neuroscience 2004). More generally, environmental manipulations can profoundly affect biology. Maternal care and stress have been associated with abnormal brain (hippocampal) development, involving altered nerve growth factors and cognitive, psychological, and immune deficits later in life.

Some argue that genetic manipulations are different because they are irreversible. But environmental interventions can equally be irreversible. Child neglect or abuse can scar a person for life. It may be impossible to unlearn the skill of playing the piano or riding a bike, once learnt. One may be wobbly, but one is a novice only once. Just as the example of mothering of rats shows that environmental interventions can cause biological changes which are passed onto the next generation, so too can 
environmental interventions be irreversible, or very difficult to reverse, within one generation.

Why should we allow environmental manipulations which alter our biology but not direct biological manipulations? What is the moral difference between producing a smarter child by immersing that child in a stimulating environment, giving the child a drug, or directly altering the child's brain or genes?

One example of a drug which alters brain chemistry is Prozac. It is a serotonin reuptake inhibitor. Early in life it acts as a nerve growth factor. But it may alter the brain early in life to make it more prone to stress and anxiety later in life, by altering receptor development (Holden 2004). People with a polymorphism that reduced their serotonin activity were more likely than others to become depressed in response to stressful experiences (Holden 2003). Both drugs like Prozac and maternal deprivation may have the same biological effects.

If the outcome is the same, why treat biological manipulation differently to environmental manipulation? Not only may a favourable environment improve a child's biology and increase a child's opportunities, so too may direct biological interventions. Couples should maximize the genetic opportunity of their children to lead a good life and a productive, cooperative social existence.

There is no relevant moral difference between environmental and genetic intervention.

\section{Third Argument: No Difference to Treating Disease.}

If we accept the treatment and prevention of disease, we should accept enhancement. The goodness of health is what drives a moral obligation to treat or prevent disease. But health is not what ultimately matters -health enables us to live well; disease prevents us from doing what we want and what is good. Health is instrumentally valuable- valuable as a resource that allows us to do what really matters, that is, lead a good life.

What constitutes a good life is a deep philosophical question. According to hedonistic theories, what is good is having pleasant experiences and being happy. According to desire fulfillment theories, and economics, what matters is having our preferences satisfied. According to objective theories, certain activities are good for people -developing deep personal relationships, developing talents, understanding oneself and the world, gaining knowledge, being a part of a family, and so on. We need not decide on which of these theories is correct to understand what is bad about ill health. Disease is important because it causes pain, is not what we want, and stops us engaging in those activities that giving meaning to life. Sometimes people trade health for well-being -mountain climbers take on risk to achieve, smokers sometimes believe that the pleasures outweigh the risks of smoking, and so on. Life is about managing risk to health and life to promote well-being.

Beneficence -the moral obligation to benefit people- provides a strong reason to enhance people in so far as the biological enhancement increases their chance of having a better life.

But can biological enhancements increase people's opportunities for well-being? There are reasons to believe they might.

Many of our biological and psychological characteristics profoundly affect how well our lives go. In the 1960s Walter Mischel conducted impulse control experiments where 4-year-old children were left in a room with one marshmallow, after being told that if they did not eat the marshmallow, they could later have two. Some children would eat it as soon as the researcher left, others would use a variety of strategies to help control their behaviour and ignore the temptation of the single marshmallow.

A decade later, they reinterviewed the children and found that those who were better at delaying gratification had more friends, better academic performance, and more motivation to succeed. Whether the child had grabbed for the marshmallow had a much stronger bearing on their SAT scores than did their IQ (Mischel 1988).

Impulse control has also been linked to socioeconomic control and avoiding conflict with the law. The problems of a hot and uncontrollable temper can be profound.

Shyness too can greatly restrict a life. I remember one newspaper story about a woman who blushed 
violet every time she went into a social situation. This led her to a hermitic, miserable existence. She eventually had the autonomic nerves to her face surgically cut. This revolutionized her life and had a greater effect on her well-being than the treatment of many diseases.

Buchanan and colleagues have discussed the value of 'all purpose goods' (Buchanan 2000). These are traits which are valuable regardless of which kind of life a person chooses to live. They give us greater all around capacities to live a vast array of lives. Examples include intelligence, memory, self-discipline, patience, empathy, a sense of humour, optimism, and just having a sunny temperament. All of these characteristics -sometimes may include virtues- may have some biological and psychological basis capable of manipulation with technology.

Technology might even be used to improve our moral character. We certainly seek through good instruction and example, discipline, and other methods to make better children. It may be possible to alter biology to make people predisposed to be more moral by promoting empathy, imagination, sympathy, fairness, honesty, etc.

In so far as these characteristics have some genetic basis, genetic manipulation could benefit us. There is reason to believe that complex virtues like fairmindedness may have a biological basis. In one famous experiment, a monkey was trained to perform a task and rewarded either a grape or piece of cucumber. He preferred the grape. On one occasion, he performed the task successfully and was given a piece of cucumber. He watched as another monkey who had not performed the task was given a grape. He became very angry. This shows that even monkeys have a sense of fairness and desert -or at least self-interest!

At the other end, there are characteristics which we believe do not make for a good and happy life. One Dutch family illustrates the extreme end of the spectrum (Brunner 1993a, Savulescu forthcoming).

For over 30 years this family recognized that there were a disproportionate number of male family members who exhibited aggressive and criminal behaviour (Morell 1993). This was characterized by aggressive outbursts resulting in arson, attempted rape, and exhibitionism (Brunner 1993b). The behaviour has been documented for almost forty years by an unaffected maternal grandfather who could not understand why some of the men in his family appeared to be prone to this type of behaviour.

Male relatives who did not display this aggressive behaviour did not express any type of abnormal behaviour. Unaffected males reported difficulty in understanding the behaviour of their brothers and cousins. Sisters of the males who demonstrated these extremely aggressive outbursts reported intense fear of their brothers. The behaviour did not appear to be related to environment and appeared consistently in different parts of the family, regardless of social context and degree of social contact.

All affected males were also found to be mildly mentally retarded with a typical IQ of about 85 (females had normal intelligence) (Brunner 1993b). When a family tree was constructed, the pattern of inheritance was clearly $\mathrm{X}$-linked recessive. This means, roughly, that women can carry the gene without being affected; $50 \%$ of men at risk of inheriting the gene get the gene and are affected by the disease.

Genetic analysis suggested that the likely defective gene was a part of the $X$ chromosome known as the Monoamine Oxidase (MAO) region. The MAO region codes for two enzymes which assist in the breakdown of neurotransmitters. Neurotransmitters are substances that play a key role in the conduction of nerve impulses in our brain. Enzymes like the monoamine oxidases are required to degrade the neurotransmitters after they have performed their desired task. It was suggested that the monoamine oxidase activity might be disturbed in the affected individuals. Urine analysis showed a higher than normal amount of neurotransmitters being excreted in the urine of affected males (Morrell 1993). These results found were consistent with a reduction in the functioning of one of the enzymes (monoamine oxidase A).

How could such a mutation result in violent and antisocial behaviour?

A deficiency of the enzyme results in a build up of neurotransmitters. These abnormal levels of neurotransmitters result in excessive, and even violent, reactions to stress. This hypothesis was further supported by the finding that genetically modified mice which lack this enzyme are more aggressive.

This family is an extreme example of how genes can influence behaviour. This mutation has only been 
isolated in this family. Most genetic contributions to behaviour will be weaker predispositions. Yet there may be some association between genes and behaviour which results in criminal prosecution and other antisocial behaviour. In one family, a mutation in monamine oxidase $A$, an enzyme in the brain, has been associated with mild intellectual disability and violent behaviour.

How could such information be used? Some criminals have attempted a "genetic defense" in the US which stated that their genes caused them to commit the crime. This has never succeeded. However, it is clear that couples should be allowed to use this test to select offspring who do not have the mutation which predisposes them to act in this way. And if interventions were available, it might be rational to correct it. Children without this mutation have a better chance of a better life.

"Genes, not men, may hold the key to female pleasure" ran the title of one recent newspaper article. It reported the results of a large study of female identical twins in Britain and Australia. It found that "genes accounted for 31 per cent of the chance of having an orgasm during intercourse and 51 per cent during masturbation". It concluded that the 'ability to gain sexual satisfaction is largely inherited' and went on to speculate that "[t]he genes involved could be linked to physical differences in sex organs and hormone levels or factors such as mood and anxiety" (The Age 2005).

Our biology profoundly affects how our lives go. If we can increase sexual satisfaction by modifying biology, we should. Indeed, vast numbers of men attempt to do this already through the use of Viagra.

\section{Summary: The Case in Favour of Enhancement.}

What matters is human well-being, not only treatment and prevention of disease. Our biology affects our opportunities to live well. The biological route to improvement is no different to the environmental. Biological manipulation to increase opportunity is ethical. If we have an obligation to treat and prevent disease, we have an obligation to try to manipulate these characteristics to give an individual the best opportunity of the best life.

\section{How do we decide?}

If we are to enhance certain qualities, how should we decide which to choose? Eugenics was the movement early last century which aimed to use selective breeding to prevent degeneration of the gene pool by weeding out criminals, those with mental illness, and the poor, on the false belief that these conditions were simple genetic disorders. The eugenics movement had its inglorious peak when the Nazis moved beyond sterilization to extermination of the genetically unfit.

What was objectionable about the eugenics movement, besides its shoddy scientific basis, was that it involved the imposition of a State vision for a healthy population and aimed to achieve this through coercion. The eugenics movement was not aimed at what was good for individuals, but rather what benefited society. Modern eugenics in the form of testing for disorders, such as Down syndrome, occurs very commonly but is acceptable because it is voluntary, gives couples a choice over what kind of child to have, and enables them to have a child with the greatest opportunity for a good life.

There are four possible ways in which our genes and biology will be decided: 1) Nature or God; 2) "Experts" -philosophers, bioethicists, psychologists, scientists; 3) "Authorities" -government, doctors; 4) By people themselves -liberty and autonomy.

It is a basic principle of liberal states like the UK that the State be 'neutral' to different conceptions of the good life. This means that we allow individuals to lead the life that they believe is best for themselves -respect for their personal autonomy or capacity for self-rule. The sole ground for interference is when that individual choice may harm others. Advice, persuasion, information, dialogue are permissible. But coercion and infringement of liberty are impermissible.

There are limits to what a liberal state should provide:

1. Safety -the intervention should be reasonably safe.

2. Harm to others -the intervention (like some manipulation that increases uncontrollable aggressiveness) 
should not result in harm. Such harm should not be direct or indirect, for example, by causing some unfair competitive advantage.

3. Distributive justice -the interventions should be distributed according to principles of justice

The situation is more complex with young children, embryos, and fetuses who are incompetent. These human beings are not autonomous and cannot make choices themselves about whether a putative enhancement is a benefit or harm. If a proposed intervention can be delayed until that human can reach maturity and decide for himself or herself, then the intervention should be delayed. However, many genetic interventions will have to be performed very early in life if they are to have an effect. Decisions about such interventions should be left to parents, according to a principle of procreative liberty and autonomy. This states that parents have the freedom to choose when to have children, how many children to have, and arguably what kind of children to have.

Just as parents have wide scope to decide on the conditions of the upbringing of their child, including schooling and religious education, they should have similar freedom over their children's genes. Procreative autonomy or liberty should be extended to enhancement for two reasons. Firstly, reproduction, bearing and raising children is a very private matter. Parents must bear much of the burden of having children and they have a legitimate stake in the nature of the child they must invest so much of their lives raising (Savulescu 2002).

But there is a second reason. John Stuart Mill argued that when our actions only affect ourselves, we should be free to construct and act on our own conception of what is the best life for us. Mill was not a libertarian. He did not believe that such freedom was solely valuable for its own sake. He believed freedom was important for people to discover for themselves what kind of life is best for themselves. It is only through "experiments in living" that people discover what works for them. And do others see the richness and variety of lives that can be good. Mill strongly praised "originality" and variety in choice as being essential to discovering which lives are best for human beings.

Importantly, Mill believed that some lives are worse than others. Famously, he said it is better to be Socrates dissatisfied than a fool satisfied. He distinguished between "higher pleasures" of "feelings and imagination" and "lower pleasures" of "mere sensation" (Mill 1910: 7). Mill criticized "ape-like imitation", subjugation of oneself to custom and fashion, indifference to individuality, and lack of originality (Mill 1910: 119-120, 123).

Nonetheless, he was the champion of people's right to live their lives as they choose.

"I have said that it is important to give the freest scope possible to uncustomary things, in order that it may appear in time which of these are fit to be converted into customs. But independence of action, and disregard of custom, are not solely deserving of encouragement for the chance they afford that better modes of action, and customs more worthy of general adoption, may be struck out; nor is it only persons of decided mental superiority who have a just claim to carry on their lives in their own way. There is no reason that all human existence should be constructed on some one or small number of patterns. If a person possesses any tolerable amount of common sense and experience, his own mode of laying out his existence is the best, not because it is the best in itself, but because it is his own mode" (Mill 1910: 125).

I believe that reproduction should be about having children with the best prospects. But to discover what are the best prospects, we must give individual couples the freedom to act on their own value judgment of what constitutes a life of good prospect. "Experiments in reproduction" are as important as "experiments in living" (as long as they don't harm the children who are produced.) For this reason, procreative freedom is important.

There is one important limit to procreative autonomy that is different to the limits to personal autonomy. The limits to procreative autonomy should be:

1. Safety.

2. Harm to others.

3. Distributive justice.

4. The parent's choices are based on a plausible conception of well-being and a better life for the child. 
5. Consistent with development of autonomy in child and a reasonable range of future life plans.

These last two limits are important. It makes for a higher standard of 'proof' that an intervention will be an enhancement because the parents are making choices for their child, not themselves. The critical question to ask in considering whether to alter some gene related to complex behaviour is: would the change be better for the individual? Is it better for the individual to have a tendency to be lazy or hardworking; monogamous or polygamous? These questions are difficult to answer. While we might let adults choose to be monogamous or polygamous, we would not let parents decide on their child's predispositions unless we were reasonably clear that some trait was better for the child. There will be cases where some intervention is plausibly in a child's interests: increased empathy with other people, better capacity to understand oneself and the world around, or improved memory. One quality is especially associated with socioeconomic success and staying out of prison: impulse control. If it were possible to correct poor impulse control, we should correct it. Whether we should remove impulsiveness altogether is another question.

Joel Feinberg has described a child's right to an open future (Feinberg 1980). An open future is one in which a child a reasonable range of possible lives to choose from and an opportunity to choose what kind of person to be. That is, to develop autonomy. Some critics of enhancement have argued that genetic interventions are inconsistent with a child's right to an open future (Davis 1997). Far from restricting a child's future, however, some biological interventions may increase the possible futures or at least their quality. It is hard to see how improved memory or empathy would restrict a child's future. Many worthwhile possibilities would be open. But is true that parental choices should not restrict the development of autonomy or reasonable range of possible futures open to a child. In general, fewer enhancements will be permitted in children than in adult. Some interventions, however, may still be clearly enhancements for our children and so just like vaccinations or other preventative health care.

\section{Objections}

\section{Playing God or Against Nature.}

This objection has various forms. Some people in society believe that children are a gift, of God or of Nature, and that we should not interfere in human nature. Most people implicitly reject this view -we screen embryos and fetuses for diseases, even mild correctible diseases. We interfere in Nature or God's will when we vaccinate, provide pain relief to women in labour (despite objections of some earlier Christians that these practices thwarted God's will) and treat cancer. No one would object to the treatment of disability in a child, if it were possible. Why then, not treat the embryo with genetic therapy if that intervention is safe? This is no more thwarting God's will than giving antibiotics.

Another variant of this objection is that we are arrogant to assume we can have sufficient knowledge to meddle with human nature. Some people object that we cannot know the complexity of the human system, which is like an unknowable magnificent symphony. To attempt to enhance one characteristic may have other unknown, unforeseen effects elsewhere in the system. We should not play God -we should be humble and recognise the limitations of our knowledge. Unlike God, we are not omnipotent or omniscient.

A related objection is that genes are pleiotropic -which means they have different effects in different environments. The gene or genes which predispose to manic depression may also be responsible for heightened creativity and productivity.

One response to both these objections is to limit our interventions, until our knowledge grows, to selections between different embryos and not intervene to enhance particular embryos or people. Since we would be choosing between complete systems on the basis of their type, we would not be interfering with the internal machinery. In this way, selection is less risky than enhancement (Savulescu, forthcoming).

But such precaution can be also misplaced when considering biological interventions. When benefits are on offer, such objections remind us to refrain from hubris and overconfidence. We must do adequate 
research before intervening. And because the benefits may be less than when we treat or prevent disease, we may require the standards of safety to be higher than for medical interventions. But we must weigh the risks against the benefit. If confidence is justifiably high, and benefits outweigh harms, we should enhance.

Once technology affords us with the power to enhance our and our children's lives, to fail to do so will be to be responsible for the consequences. To fail to treat our children's disease, is to wrong them. To fail to prevent them getting depression, is to wrong them. To fail to improve their physical, musical, psychological, and other capacities is to wrong them, just as it would be to harm them if we gave them a toxic substance that stunted or reduced these capacities.

Another variant of the "Playing God" objection is that there is a special value in the balance and diversity that natural variation affords, and enhancement will reduce this. But in so far as we products of evolution, we are merely random chance variations of genetic traits selected for our capacity to survive long enough to reproduce. There is no design to evolution. Evolution selects genes according to environment which confer the greatest chance of survival and reproduction. Evolution would select a tribe which was highly fertile but suffered great pain the whole of their lives over another tribe which was less fertile but suffered less pain. Medicine has changed evolution -we can now select individuals who experience less pain and disease. The next stage of human evolution will be rational evolution, where we select children who not only have the greatest chance of surviving, reproducing, and being free of disease, but who have the greatest opportunities to have the best lives in their likely environment. Evolution was indifferent to how well our lives went. We are not. We want to retire, play golf, read, and watch our grandchildren have children.

Enhancement is a misnomer. It suggests luxury. But enhancement is no luxury. In so far as it promotes well-being, it is the very essence of what is necessary for a good human life.

There is no moral reason to preserve some traits -such as uncontrollable aggressiveness, a sociopathic personality, or extreme deviousness. Tell the victim of rape and murder that we must preserve the natural balance and diversity.

\section{Genetic Discrimination.}

Some people fear the creation of a two class society of the enhanced and the unenhanced, where the inferior unenhanced are discriminated against and disadvantaged all through life.

We must remember that nature alots advantage and disadvantage with no gesture to fairness. Some are born horribly disadvantaged, destined to die after short and miserable lives. Some suffer great genetic disadvantage while others are born gifted, physically, musically, or intellectually. There is no secret that there are 'gifted' children naturally. Allowing choice to change our biology will, if anything, be more egalitarian -allowing the ungifted to approach the gifted. There is nothing fair about the natural lottery -allowing enhancement may be more fair.

But more importantly, how well the lives of those who are disadvantaged go depends not on whether enhancement is permitted, but on the social institutions we have in place to protect the least well off and provide everyone with a fair go. People have disease and disability -egalitarian social institutions and laws against discrimination are designed to make sure everyone, regardless of natural inequality, has a decent chance of a decent life. This would be no different if enhancement were permitted. There is no necessary connection between enhancement and discrimination, just as there is no necessary connection between curing disability and discrimination against people with disability.

\section{The Perfect Child, Sterility and Loss of the Mystery of Life.}

If we engineered perfect children, this objection goes, the world would be a sterile, monotonous place where everyone is the same, and the mystery and surprise of life is gone.

It is impossible to create perfect children. We can only attempt to create children with better opportunities of a better life. There will necessarily be difference. Even in the case of screening for disability, like Down syndrome, $10 \%$ of people choose not to abort a pregnancy known to have Down syndrome. People value different things. There will never be complete convergence. Moreover, there will remain massive 
challenges for individuals to meet in their personal relationships and in the hurdles our unpredictable environment presents. There will remain much mystery and challenge -we will just be better able to deal with these. We will still have to work to achieve, but our achievements may have greater value.

\section{Against human nature.}

One of the major objections to enhancement is that it is against human nature. Common alternative phrasings are that enhancement is tampering with our nature or an affront to human dignity. I believe that what separates us from other animals is our rationality, our capacity to make normative judgements and act on the basis of reasons (Savulescu 2003). When we make decisions to improve our lives by biological and other manipulations, we express our rationality and express what is fundamentally important about our nature. And if those manipulations improve our capacity to make rational and normative judgements, they further improve what is fundamentally human. Far from being against the human spirit, such improvements express the human spirit. To be human is to be better.

\section{Enhancements are self-defeating.}

Another familiar objection to enhancement is that enhancements will have self-defeating or other adverse social effects. A typical example is increase in height. If height is socially desired, then everyone will try to enhance the height of their children at great cost to themselves and the environment (as taller people consume more resources), with no advantage in the end since there will be no relative gain.

If a purported manipulation does not improve well-being or opportunity, there is no argument in favour of it. In this case, the manipulation is not an enhancement. In other cases, such as enhancement of intelligence, the enhancement of one individual may increase that individual's opportunities only at the expense of another. So-called positional goods are goods only in relative sense.

But many enhancements will have both positional and non-positional qualities. Intelligence is good not just because it allows an individual to be more competitive for complex jobs, but because it allows an individual to more rapidly process information in her own life, and to develop greater understanding of herself and others. These non- positional effects should not be ignored. Moreover, even in the case of so-called purely positional goods, such as height, there may be important non-positional values. It is better to be taller to be a basketball player, but being tall is a disadvantage in balance sports such as gymnastics, skiing, and surfing.

Nonetheless, if there are significant social consequences of enhancement, this is of course a valid objection. But it is not particular to enhancement -there is an old question about how far individuals in society can pursue their own self-interest at cost to others. It applies to education, health care, and virtually all areas of life.

Not all enhancements will be ethical. The critical issue is that the intervention is expected to bring about more benefits than harms to the individual. It must be safe and there must be a reasonable expectation of improvement. Some of the other features of ethical enhancements are summarised below.

What is an ethical enhancement?

1. It is in the person's interests.

2. Reasonably safe.

3. Increases the opportunity to have the best life.

4. Promotes or does not unreasonably restrict the range of possible lives open to that person.

5. Does not harm others directly through excessive costs of making it freely available (but balance against the costs of prohibition).

6. Does not place that individual at an unfair competitive advantage with respect to others, e.g. mind reading.

7. The person retains significant control or responsibility for her achievements and self which cannot be wholly or directly attributed to the enhancement.

8. Does not reinforce or increase unjust inequality and discrimination -economic inequality, racism. (But balance the costs of social/environmental manipulations against biological manipulations). 
All the above plus:

1. The intervention cannot be delayed until the child can make its own decision

2. The intervention is plausibly in child's interests

3. The intervention is compatible with the development of autonomy.

\section{Conclusion}

Enhancement is already occurring. In sport, human erythropoietin boosts red blood cells. Steroids and growth hormone improve muscle strength. Many people seek cognitive enhancement -nicotine, ritalin, modavigil, caffeine. Prozac, recreational drugs, and alcohol all enhance mood. Viagra is used to improve sexual performance.

And of course mobile phones and aeroplanes are examples of external enhancing technologies. In the future, genetic technology, nanotechnology, and artificial intelligence may profoundly affect our capacities.

Will the future be better or just disease-free? We need to shift our frame of reference from health to life enhancement. What matters is how we live. Technology can now improve that. We have two options:

1. Intervention: treating disease, preventing disease, supraprevention of disease -preventing disease in a radically unprecedented way, protection of well-being; enhancement of well-being

2. No intervention, and to remain in a state of nature - no treatment or prevention of disease, no technological enhancement.

I believe to be human is to be better. Or, at least, to strive to be better. We should be here for a good time, not just a long time. Enhancement, far from being merely permissible, is something we should aspire to achieve.

* (C) By permission of Oxford University Press. Extracto del cap. 22, pp. 516-535, de Julian Savulescu (2007), "Genetic Interventions and The Ethics of Enhancement of Human Beings", en Bonnie Steinbock (Ed.), The Oxford Handbook of Bioethics. Este artículo queda expresamente excluido de la licencia Creative Commons bajo la que se publican habitualmente todas las contribuciones en Gazeta de Antropología. Cualquier uso requiere permiso de OUP (academic.permissions@oup.com)

(C) By permission of Oxford University Press. Extracts from pp. 516-535, Ch.22, 'Genetic Interventions and the Ethics of Enhancement of Human Beings' by Julian Savulescu from "Oxford Handbook of Bioethics" edited by Steinbock, Bonnie (2007). This article is expressly excluded from the general Creative Commons license used in Gazeta de Antropología. For permissions, please contact academic.permissions@oup.com

\section{References}

Agar, N.

2003 Liberal Eugenics. Oxford, Blackwell.

Annas, G.

2000 "The man on the moon, immortality and other millennial myths: the prospects and perils of human genetic engineering", Emory Law Journal, no 49 (3): 753-782.

Anon.

2005 "Genes, not men, may hold the key to female pleasure", The Age, (June 9). 
Brunner, H. G. (and others)

1993a "X-linked Borderline Mental Retardation with Prominent Behavioural Disturbance: Phenotype, Genetic Localization, and Evidence for Disturbed Monoamine Metabolism", American Journal of Human Genetics, n 52: 1032-1039.

1993b "Abnormal Behaviour Associated with a Point Mutation in the Structural Gene for Monoamine Oxidase A", Science, nº 262 (5133): 578-580.

Buchanan, A. (and others)

2000 From Chance to Choice. Cambridge, Cambridge University Press.

Cheitlin (and others)

1999 “ACC/AHA Expert Consensus Document”, JACC, nº 33 (1): 273-282.

Davis, D.

1997 "The right to an open future", Hastings Center Report, Mar/Apr.

Dellen, A. van (and others)

2000 "Delaying the onset of Huntington's in mice", Nature, n 404: 721-722.

De Marchi (and others)

2001 "Fluoxetine in the treatment of Huntington's disease", Psychopharmacology, $\mathrm{n}^{\circ} 153$ (2): 264-266.

Dickens, W. (and J. Flynn)

2001 "Heritability Estimates Versus Large Environmental Effects: The IQ Paradox Resolved", Psychological Review, no 108 (2): 346-369.

Elliott, C.

2003 Better Than Well: American Medicine Meets the American Dream. New York, W.W. Norton \& Company.

Feinberg, J.

1980 "The child's right to an open future", in W. Aiken and H. LaFollette (eds.), Whose Child? Parental Rights, Parental Authority and State Power, Totowa, NJ, Rowman and Littlefield: 124-53.

Fukuyama, F.

2003 Our Posthuman Future: Consequences of the Biotechnology Revolution. London, Profile.

Habermas, J.

2003 The Future of Human Nature. Cambridge, Polity Press.

Harris $\mathrm{J}$.

2000 "Intimations of Immortality", Science, $\mathrm{n}^{\circ} 288$ Iss (5463): 59.

2002 "Intimations of Immortality - The ethics and justice of life extending therapies", in Michael Freeman (ed.), Current Legal Problems. Oxford, Oxford University Press: 65-95.

2004 "Immortal Ethics", in de Grey ADNJ (ed.), Strategies for Engineered Negligible Senescence: Why Genuine Control of Aging May Be Foreseeable, Annals NY Acad Sci: 1019.

Holden, C.

2003 "Don't Go Off the Prozac", Science, n 301 (8 Aug.): 760.

DOI: $10.1126 /$ science.301.5634.760b

2004 "Treatment of Newborn Mice Raises Anxiety", Science, nº 306 (29 Oct.): 792.

DOI: $10.1126 /$ science.306.5697.792

Holloway, M.

1999 "Flynn's Effect", Scientific American [online], Available at: http://www.sciam.com/article.cfm?articleID=00037F65-D9C0-1C6A- 84A9809EC588EF21\&ref=sciam [4/2/2006]. 
Kamm, F.

2005 "Is there a problem with enhancement?", $A J O B, \mathrm{n}^{\circ} 5$ (3): 5-14.

Kass, L. R.

2002 Life, Liberty and the Defense of Dignity: The Challenge for Bioethics. San Francisco, Encounter Books.

Lim, M.

2004 In Nature, no 429: 754-757.

Liu, Z. J. (and others)

2004 "DNA targeting of rhinal cortex D2 receptor protein reversibly blocks learning of cues that predict reward", PNAS, nº 101 (33): 12336-12341.

Mill, J. S.

1910 On Liberty. London, J. M. Dent and Sons.

Mischel, W. (and others)

1988 "The nature of adolescent competencies predicted by preschool delay of gratification", Journal of Personality \& Social Psychology, nº 54 (4): 687-696.

Morell, V.

1993 “Evidence Found for a Possible 'Aggression Gene'”, Science, nº 260: 1722-1723.

Murray, T.

2006 [chapter] in Steinbok, B. (ed.), Oxford Handbook on Bioethics. Oxford, OUP.

Palma, V. (and others)

2005 "Sonic hedgehog controls stem cell behaviour in the postnatal and adult brain", Development, $\mathrm{n}^{\circ}$ 132: $335-344$.

President's Council on Bioethics

2003 Beyond Therapy: Biotechnology and the Pursuit of Happiness. New York, Dana Press.

Rietze, R. (and others)

2001 "Purification of a pluripotent neural stem cell from the adult mouse brain", Nature, no 412: 736-739.

Sandel, M.

2004 "The Case Against Perfection", Atlantic Monthly, April 2004: 51-62.

Savulescu, J.

2002 "Deaf lesbians, 'designer disability', and the future of medicine”, BMJ, nº 325 (7367): 771-773.

2003 "Human-animal transgenesis and chimeras might be an expression of our humanity", Am J Bioethics, $\mathrm{n}^{\circ} 3$ (3): 22-25.

Society for Neuroscience

2004 Early Life Stress harms Mental Function And Immune System in later Years According to New Research. Available at:

http://apu.sfn.org/content/AboutSFN1/NewsReleases/am2004 early.html [2/2006].

Spires, T. (and others)

2004 "Environmental Enrichment Rescues Protein Deficits in a Mouse Model of Huntington's Disease, Indicating a Possible Disease Mechanism", The Journal of Neuroscience, n 24 (9): 2270-2276.

Sullivan, F. R. (and others)

2001 "Remotivation therapy and Huntington's disease", Journal of Neuroscience Nursing, $\mathrm{n}^{\circ} 33$ (3): 136-142.

2005 "Highly efficient endogenous human gene correction using designed zinc-finger nucleases", Nature, 
no 435: 646-651.

Gazeta de Antropología 